\title{
Resistance Profile From Staphylococcus Aureus And Pseudomonas Aeruginosa Obtained From Tracheostomized Children
}

\author{
Juliana Afonso de Almeida
}

Universidade Federal de Goias

Caroline Espíndola de Barros

Universidade Federal de Goias

Gustavo Henrique da Silva Ayres

Universidade Federal de Goias

Mariana Helena e Silva

Universidade Federal de Goias

Andressa Santos Liberal

Universidade Federal de Goias

Marcos Antonio Batista

Universidade Federal de Goias

Raylane Pereira Gomes

Universidade Federal de Goias

Arlindo Rodrigues Galvão Filho

Universidade Federal de Goias

Carla Afonso da Silva

Universidade Federal de Goias

Isabela Jubé Wastowski

Universidade Federal de Goias

Lilian Carla Carneiro ( $\nabla$ carlacarneirolilian@gmail.com )

Universidade Federal de Goias https://orcid.org/0000-0003-4067-1506

Melissa Ameloti Gomes Avelino

Universidade Federal de Goias

Research

Keywords: anti-bacterial agents, resistance, beta-lactamases, pediatrics, biofilm.

Posted Date: February 21st, 2020

DOI: https://doi.org/10.21203/rs.2.23521/v2 
License: (c) (i) This work is licensed under a Creative Commons Attribution 4.0 International License. Read Full License 


\section{Abstract}

Background The tracheostomized patients exhibit high risks of bacterial infections, because the tracheal tube acts as a gateway to these microorganisms. The objective was to characterize microbiologically the tracheal secretion of tracheostomized children, to evaluate the biofilm formation, and to study the phenotypic and molecular profile of antimicrobial resistance of Staphylococcus aureus and Pseudomonas aeruginosa isolated. Methods The study collected 88 tracheal secretion samples. The material processed by phenotypic tests were performed for bacterial identification. For identification of the biofilm, the Congo red agar test and the plaque microtiter test were used, and the GPCR method was used to resistance verification. Results Were obtained 27 samples of S. aureus and 71 of P. aeruginosa . All S. aureus samples were positive for biofilm formation on Congo red agar test. In antibiogram test, S. aureus showed resistance to seven drugs. Regarding the identification of resistance genes, were amplificated bla Z in $42.8 \%$ from $\mathrm{S}$. aureus and mec $\mathrm{A}$ in $28.6 \%$ of them. Pseudomonas aeruginosa presented resistance to eight drugs. The most frequent chromosomal genes were bla OXA with $66.7 \%$ and bla KPC with $58.3 \%$. To plasmidial DNA, was highlighted bla NDM with $58.3 \%$ positive. Conclusion The S. aureus and $\mathrm{P}$. aeruginosa characterization of colonization from lower respiratory tract associated with the use of the device in tracheotomy patients, and the physiology and antimicrobial resistance profile, will help health professionals to choose the most appropriate treatment to be administered in children with tracheotomy, increasing the chances of airway restoration and decannulation.

\section{Introduction}

Tracheostomy consists of a surgical opening in the anterior tracheal wall, into which a tracheal cannula is inserted. It's indicated in respiratory obstruction cases, subglottic stenosis, tracheomalacia and craniofacial syndromes, as well as providing access to the lower respiratory tract in cases as neurological and neuromuscular diseases ${ }^{1}$.

Due the lack of protection as filtration, humidification and air heating, performed by the upper respiratory tract, tracheostomized patients exhibit high risks of virus and bacterial infections, because the tracheal tube acts as a gateway to these microorganisms ${ }^{2,3,4}$. The contamination and the consequent lower respiratory tract colonization are facilitated, and the main bacteria found were Pseudomonas aeruginosa and Staphylococcus aureus ${ }^{5,6}$. Both microorganisms exhibit high resistance rates to $\beta$-lactams, the most commonly group used in medical routine ${ }^{7}$.

In addition, bacteria that are frequently found in tracheostomy tubes are biofilm-forming, such as $S$. aureus often associated with lower respiratory tract infections ${ }^{1,3,8,9,10}$.

Besides, others resistance factors dissemination can be attributed to the genetic mutational processes and genetic material exchange, because of selective environmental pressure and multiresistant clone's proliferation ${ }^{10}$. Through is possible the plasmids transport resistant genes, that codes antibacterial information's, becoming the bacteria multiresistant. The mechanisms that become bacteria resistant are 
decreased permeability of both wall and cytoplasmic membrane; target site antibiotics alteration; antibiotic expulsion by efflux pumps and $\beta$-lactamases enzymes production that inactivate the antibiotic.

These mechanisms come from mutational processes and/or genetic material exchange ${ }^{11,12}$.

The indiscriminate antimicrobials use can lead to individual's normal microbiota alteration, which increases the risks of acquisition and colonization of resistant bacteria, as may select resistant microorganisms that exist in the airways. This may origins an increase in costs to the patient because of increased length of stay in hospitals, besides the prevention and treatment difficult ${ }^{13}$.

To prevent possible respiratory infections, tracheostomized patients should exchange tracheostomy tube once a month, but the non-availability of the cannula by the Brazilian Public Health System, contributes to increase of change time, because patients have to pay for the device and the most of time don't have financial resources to do it. The aim of this research was to study the physiology and antimicrobial resistant profile by phenotypic and molecular methods of $P$. aeruginosa and $S$. aureus obtained from tracheostomized children tracheal secretion.

\section{Methods}

The research project was approved by the Ethics Committee of the Clinical Hospital of the Federal University of Goiás (CEP/HC/UFG), by number 32091014.6.1001.5078. Were isolated 27 S. aureus samples and $71 P$. aeruginosa samples, obtained from tracheotomized pediatric patients' tracheal secretion. The samples were obtained from a terciary universitary hospital in Goiania's city.

Eighty-eight tracheal secretion samples were collected from 11 tracheostomized children, with age between zero months to eighteen years old, that using the tracheostomy cannula to ventilatory support and were not infected or with symptoms like fever, increased discharge, productive cough or any other unusual symptoms. Samples were collected prior to cannula removal and were taken twice each season, during the time of cannula replacement, which was performed between 30 and 45 days, according to the protocol.

The samples were collected from May 2017 to October 2018, the first being performed in autumn and the others in the following order: winter, spring and summer.

To collect of the secretion, the contents were aspirated with a syringe containing physiological solution, coupled to a probe, which was introduced into the tracheostoma, and the physiological solution was injected into it. The aspirated contents were deposited in a sterile vial and immediately sent for processing in the laboratory.

\section{Microbiological analysis}

Samples were sown in salty mannitol, MacConkey, chocolate and blood culture media. Cultures were incubated for 24 hours at $37^{\circ} \mathrm{C}$ under aerobic conditions. After this period, the morphocolonial and 
morphotintorial characterization was performed, as well as biochemical tests to identify isolated colonies, according to Procop and collaborators ${ }^{14}$ and the ANVISA manual ${ }^{15}$.

Biofilm production was analyzed according to FREEMAN et al ${ }^{16}$ and Tendolkar et al. ${ }^{17}$, with adaptations.

\section{Antibiogram test}

The $P$. aeruginosa and $S$. aureus samples were subjected to the antibiogram test using the Kirby and Bauer method ${ }^{18}$. To $P$. aeruginosa, were used discs of Ceftazidime (CAZ) $30 \mu \mathrm{g}$, Imipenem (IPM) $10 \mu \mathrm{g}$, Gentamicin (GEN) $10 \mu \mathrm{g}$, Ciprofloxacin (CIP) $5 \mu \mathrm{g}$, Piperacillin and Tazobactam associated (PPT) 100/10 $\mu \mathrm{g}$, Aztreonam (ATM) $30 \mu \mathrm{g}$ and Cefepime (CPM) $10 \mu \mathrm{g}$. To S. aureus were used Ciprofloxacin (CIP) $5 \mu \mathrm{g}$, Cefoxitin (CFO) $30 \mu \mathrm{g}$, Gentamicin (GEN) $10 \mu \mathrm{g}$, Penicillin (PEN) $10 \mu \mathrm{g}$, Clindamycin (CLI) $2 \mu \mathrm{g}$, Erythromycin (ERI) $15 \mu \mathrm{g}$, Sulfamethoxazole and Trimetoprim associated (SUT) $30 \mu \mathrm{g}$, Linezolid (LNZ) 30 $\mu \mathrm{g}$, Rifampicin (RIF) $5 \mu \mathrm{g}$ e Tetracycline (TET) $30 \mu \mathrm{g}$, as recommended by $\mathrm{CLSI}^{19}$.

For $S$. aureus, clindamycin resistance induction test, called $D$ test, was performed to detected resistance to macrolides, lincosamines and streptogramins. Was also evaluated the oxacillin resistance mecA gene mediated. To evaluate the activity of $\beta$-lactamase resistance mediated by blaZ gene, was considered the penicillin halo measurement. Pseudomonas aeruginosa tests were performed to evaluate the $\beta$ lactamases enzymes activity type AmpC, Extended Spectrum $\beta$-Lactamase (ES $\beta \mathrm{L})$, metallo- $\beta$-lactamase and carbapenemase, using the disc difusion method, according to ANVISA methodology ${ }^{15}$

\section{Resistance genes amplification}

The samples with positive resistance, phenotypic tests were used to plasmid and chromosomal DNA extraction, according Pharmacia ${ }^{\circledR}$ Flexiprep extraction kit manual.

For $S$. aureus, specific primers blaZ and mecA genes were designed for one of the authors. Was also used primer for femA gene to confirm the $S$. aureus phenotypic identification, according to store sequences in GenBank 20,21 .

For $P$. aeruginosa, specific primers for blaVIM, blaKPC, blaSHV, blaOXA, blaCMY, blaIMP, blaNDM e blaTEM genes were designed by one of the authors, based on literature 22, 23, 24, 25, 26. The qPCR technique conditions were performed according to the manufacturer's instructions.

\section{Statistical analysis}

For percentage analysis and graphs, Microsoft Excel (Microsoft Corp., Redmond, WA, USA) was used. To associate the data obtained in the antibiogram test for phenotypic resistance and susceptibility, and the presence or absence of the resistance genes observed along with the seasons of the year, the MATLAB script (version 8.1, Natwick, USA) was applied using the test Chi-square. 


\section{Results}

Among the 11 participants, a total of 88 tracheal secretion samples were obtained and 193 bacterial colonies from 41 different species were isolated, 15 classifieds as gram positive and 26 classified as gram negative. For several patients, there was concomitant isolation of more than one type of bacteria.

Among the gram positive bacteria, we highlight Corynebacterium spp., isolated in most patients in all seasons of the year. Coagulase negative Staphylococcus (SCN) and S. aureus were also isolated in all seasons. From the CNS isolates the following species were identified: $S$. epidermidis, $S$. haemolyticus, $S$. hominis and S. Iugdunensis. Planococcus spp., S. schileiferi and Stomatococcus spp. were the least prevalent, being found in one patient in spring, autumn and summer respectively (Table 1).

Table 1 - Presence of bacteria in tracheal secretions of tracheostomized children, according to seasons and number of patients. 


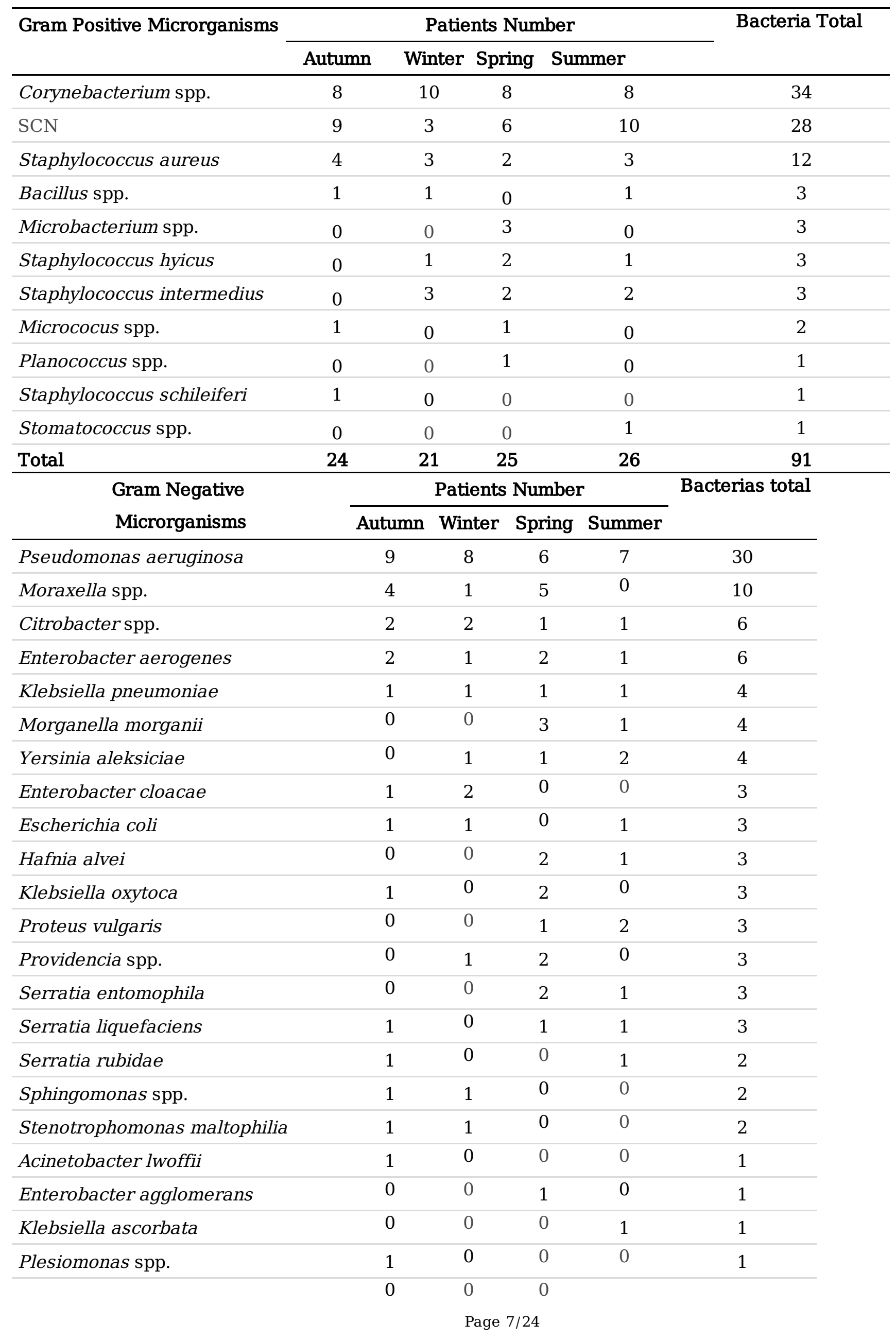




\begin{tabular}{lccccc} 
Serratia grimesii & & & 1 & 1 \\
Serratia marcescens & 1 & 0 & 0 & 0 & 1 \\
\hline Serratia odorífera & 1 & 0 & 0 & 0 & 1 \\
\hline Tatumella cítrea & 0 & 0 & 0 & 1 & 1 \\
\hline Total & $\mathbf{2 9}$ & $\mathbf{2 0}$ & $\mathbf{3 0}$ & $\mathbf{2 3}$ & $\mathbf{1 0 2}$ \\
\hline
\end{tabular}

Subtitle: CNS: Coagulase Negative Staphylococcus.

Analyzing the number and diversity of bacterial species with respect to seasonality, it can be observed that in summer 25 different species of bacteria were isolated, followed by autumn and spring with 24 species and 18 species in winter. As for the number of isolated bacteria, autumn and spring were the seasons with the highest number of isolates, followed by winter and summer (Figure 1).

Observing the diversity individually, it is noteworthy that in three patients ${ }^{27,28}$ the isolated microbiota varied in all seasons in an equalized manner, which shows that the seasons may not have interference in the microbiota diversity (Table 2).

Table 2 - Diversity of bacterial species isolated in tracheal secretions according to each tracheostomized patient.

\begin{tabular}{lcccc}
\hline Patients & \multicolumn{4}{c}{ Species Diversity } \\
\cline { 2 - 5 } & Autumn & Winter & Spring & Summer \\
\hline Paciente 1 & 4 & 6 & 7 & 4 \\
\hline Paciente 2 & 2 & 4 & 3 & 6 \\
\hline Paciente 3 & 3 & 3 & 6 & A \\
\hline Paciente 4 & 6 & 2 & 8 & A \\
\hline Paciente 5 & 3 & 3 & 2 & 4 \\
\hline Paciente 6 & 7 & 5 & 9 & 6 \\
\hline Paciente 7 & 5 & 4 & 2 & 5 \\
\hline Paciente 8 & 6 & 4 & 3 & 6 \\
\hline Paciente 9 & 8 & 5 & 5 & 6 \\
\hline Paciente 10 & 5 & 3 & 11 & 4 \\
\hline Paciente 11 & 8 & 2 & A & 8 \\
\hline
\end{tabular}

Subtitle: A: Patient absent from collection. 
For the biofilm production tests, we chose the species of clinical importance that were most prevalent in the patients and were present in all seasons of the year. Thus, biofilm production was evaluated in 12 isolates of $S$. aureus.

Despite Corynebacterium spp. was the most prevalent specie, the phenotypic test was not performed to verify biofilm production, as this bacterium is not commonly associated with respiratory infections. Regarding the CNS, although they were also prevalent, when evaluated separately, they were not isolated in all seasons of the year.

To the experiments using Congo Red Agar, only isolates of $S$. aureus were tested, since the test does not show effectiveness for $P$. aeruginosa samples, including the positive control strain, known as biofilmforming. All isolates of $S$. aureus (12) were positive in Congo red agar, and therefore all biofilm-forming.

As for biofilm adhesion intensity, P. aeruginosa isolated were $50 \%$ weakly, $20 \%$ moderately and $30 \%$ strongly adherent. Staphylococcus aureus isolated were $8 \%$ weakly, $42 \%$ moderately and $50 \%$ strongly adherent (Figure 2).

Tests to observe the antimicrobial resistance were performed in $27 \mathrm{~S}$. aureus isolates. In the D test, $51.8 \%$ $(14 / 27)$ had a positive result. In the antimicrobial susceptibility test of $S$. aureus, it can be highlighted that among the 27 isolates tested, $100 \%$ were resistant to penicillin, $70.4 \%(19 / 27)$ to cefoxitin/oxacillin and $66.7 \%(18 / 27)$ to erythromycin (Figure 3$)$.

Regarding the resistant genes amplification in the $S$. aureus tested samples, $42.8 \%(3 / 7)$ isolates containing blaZ in plasmid and chromosomal DNA was identified. The mecA gene was amplified in $28.6 \%(2 / 7)$ isolates. These genes were identified in $85.7 \%(6 / 7)$ different isolates. The femA gene was amplified in $100 \%$ of the samples (Table 3 ).

Table 3 - Amplification of blaZ, mecA and femA genes in Staphylococcus aureus samples isolated from tracheostomized children tracheal secretion. 


\begin{tabular}{c|c|c|c|c}
\hline Isolates & Gene Localization & \multicolumn{3}{|c}{ Resistance Genes } \\
\cline { 3 - 5 } & & blaZ & mecA & femA \\
\hline \multirow{2}{*}{1} & $\mathrm{P}$ & 1 & 0 & 0 \\
\cline { 2 - 5 } & $\mathrm{C}$ & 2 & 2 & 1 \\
\hline \multirow{2}{*}{2} & $\mathrm{P}$ & 1 & 0 & 0 \\
\cline { 2 - 5 } & $\mathrm{C}$ & 1 & 2 & 1 \\
\hline \multirow{2}{*}{3} & $\mathrm{P}$ & 2 & 0 & 0 \\
\cline { 2 - 5 } & $\mathrm{C}$ & 2 & 1 & 1 \\
\hline \multirow{2}{*}{4} & $\mathrm{P}$ & 2 & 0 & 0 \\
\cline { 2 - 5 } & $\mathrm{C}$ & 2 & 2 & 1 \\
\hline \multirow{2}{*}{5} & $\mathrm{P}$ & 2 & 0 & 0 \\
\hline \multirow{2}{*}{6} & $\mathrm{C}$ & 2 & 1 & 1 \\
\cline { 2 - 5 } & $\mathrm{P}$ & 1 & 0 & 0 \\
\hline \multirow{2}{*}{7} & $\mathrm{C}$ & 1 & 2 & 1 \\
\cline { 2 - 5 } & $\mathrm{P}$ & 2 & 0 & 0 \\
\hline
\end{tabular}

Subtitle: P: Plasmidial; C: Chromosomal; 0: no avaliated; 1: Gene presence; 2: Gene absences.

For S. aureus isolates the phenotypic association occurred between the antibiotic tested cefoxitin with erythromycin and penicillin, all with $p$-value $<0.01$. There was no statistically phenotypic association with the genotypic results and between the analyzed genes, as well as no variation and statistical association between the seasons and the data obtained.

In the data obtained for $P$. aeruginosa, we can highlight resistance of $23.9 \%(17 / 71)$ for aztreonam and $12.7 \%(9 / 71)$ for imipenem (Figure 4). In the phenotypic test to evaluate the $\beta$-lactamase activity, all were negative to $E S \beta L$, metallo- $\beta$-lactamase and carbapenemase.

Based on the resistance found in $P$. aeruginosa antibiogram test, the literature search showed 12 genes responsible for $\beta$-lactams resistance (dates not shown).

In $P$. aeruginosa, of the 12 genes researched, 10 were found in plasmid DNA and 10 in chromosomal DNA. Among the samples tested, the most frequent chromosomal genes were blaOXA with $66.7 \%(8 / 12)$, blaKPC with $58.3 \%$ (7/12), blaVIM e blaCMY with $41.7 \%$ (5/12) of positivity. For plasmid DNA, were highlighted blaNDM with 58.3\% (7/12), blaSHV, blaOXA e blaTEM with $41.7 \%(5 / 12)$ of positivity (Figure $5)$.

For the genetic difference identified in each strain of $P$. aeruginosa researched, can highlight the samples " $D$ " with nine different gene types on chromosome and five on plasmid; sample "G" with seven types on chromosome and eight on plasmid; samples " $\mathrm{H}$ " with five types on chromosome and seven non plasmid and sample "B" showing seven gene types on chromosome and one on plasmid (Table 4).

Table 4 - Amplification of Pseudomonas aeruginosa resistance genes isolated from tracheostomized pediatric patients, according to DNA origin.

Subtitle: C: Chromosomal; P: Plasmidial; 0: no avaliated; 1: Gene absence; 2: Gene presence.

Source: BUSH; JACOBY (2010). 


\begin{tabular}{|c|c|c|c|c|c|c|c|c|c|c|c|c|c|c|}
\hline \multirow[t]{2}{*}{ Isolated } & \multirow{2}{*}{$\begin{array}{c}\text { Gene } \\
\text { Localization }\end{array}$} & \multicolumn{12}{|c|}{ Resistance Genes } & \multirow{2}{*}{$\begin{array}{c}\text { Total } \\
\text { of } \\
\text { genes }\end{array}$} \\
\hline & & blaSPM & blaSIM & blaVIM & blaKPC & blaSHV & $\begin{array}{c}\text { blaCTX- } \\
\text { M }\end{array}$ & blaOXA & blaIMP & blaNDM & blaSME & blaCMY & blaTEM & \\
\hline A & $\mathrm{C}$ & 0 & 0 & 1 & 1 & 1 & 1 & 0 & 0 & 0 & 0 & 1 & 1 & 0 \\
\hline \multirow[t]{2}{*}{ B } & $\mathrm{P}$ & 0 & 0 & 1 & 1 & 2 & 0 & 1 & 0 & 1 & 0 & 1 & 1 & 1 \\
\hline & $\mathrm{C}$ & 0 & 0 & 2 & 2 & 2 & 2 & 2 & 0 & 2 & 0 & 2 & 1 & 7 \\
\hline \multirow[t]{2}{*}{$\mathrm{C}$} & $\mathrm{P}$ & 1 & 1 & 1 & 1 & 0 & 0 & 2 & 1 & 2 & 0 & 0 & 0 & 2 \\
\hline & $\mathrm{C}$ & 0 & 0 & 2 & 2 & 0 & 0 & 2 & 2 & 1 & 1 & 0 & 0 & 4 \\
\hline \multirow[t]{2}{*}{$\mathrm{D}$} & $\mathrm{P}$ & 1 & 0 & 1 & 1 & 2 & 0 & 1 & 2 & 2 & 0 & 2 & 2 & 5 \\
\hline & $\mathrm{C}$ & 0 & 0 & 2 & 2 & 2 & 2 & 2 & 2 & 2 & 0 & 2 & 2 & 9 \\
\hline \multirow[t]{2}{*}{$\mathrm{E}$} & $\mathrm{P}$ & 1 & 1 & 1 & 1 & 0 & 0 & 1 & 1 & 1 & 0 & 0 & 0 & 0 \\
\hline & $\mathrm{C}$ & 0 & 0 & 1 & 2 & 0 & 0 & 2 & 1 & 1 & 2 & 0 & 0 & 3 \\
\hline \multirow[t]{2}{*}{$\mathrm{F}$} & $\mathrm{P}$ & 0 & 0 & 1 & 1 & 1 & 0 & 1 & 0 & 2 & 0 & 1 & 1 & 1 \\
\hline & $\mathrm{C}$ & 0 & 0 & 1 & 2 & 1 & 1 & 1 & 0 & 2 & 0 & 2 & 2 & 4 \\
\hline \multirow[t]{2}{*}{$\mathrm{G}$} & $\mathrm{P}$ & 1 & 0 & 2 & 2 & 2 & 0 & 2 & 2 & 2 & 0 & 2 & 2 & 8 \\
\hline & $\mathrm{C}$ & 0 & 0 & 2 & 2 & 2 & 2 & 2 & 1 & 1 & 0 & 2 & 2 & 7 \\
\hline \multirow[t]{2}{*}{$\mathrm{H}$} & $\mathrm{P}$ & 2 & 1 & 2 & 1 & 2 & 0 & 2 & 1 & 2 & 0 & 2 & 2 & 6 \\
\hline & $\mathrm{C}$ & 0 & 0 & 2 & 2 & 1 & 2 & 2 & 2 & 1 & 1 & 1 & 1 & 5 \\
\hline \multirow[t]{2}{*}{ I } & $\mathrm{P}$ & 0 & 0 & 1 & 2 & 2 & 0 & 1 & 0 & 2 & 0 & 1 & 1 & 3 \\
\hline & $\mathrm{C}$ & 0 & 0 & 1 & 1 & 1 & 1 & 1 & 0 & 1 & 0 & 2 & 1 & 1 \\
\hline \multirow[t]{2}{*}{$\mathrm{J}$} & $\mathrm{P}$ & 1 & 0 & 2 & 1 & 1 & 0 & 2 & 2 & 2 & 0 & 1 & 2 & 5 \\
\hline & $\mathrm{C}$ & 0 & 0 & 1 & 1 & 2 & 1 & 2 & 1 & 2 & 0 & 1 & 2 & 4 \\
\hline $\mathrm{K}$ & $\mathrm{P}$ & 1 & 1 & 1 & 2 & 0 & 0 & 1 & 2 & 1 & 0 & 0 & 0 & 2 \\
\hline \multirow[t]{2}{*}{$\mathrm{L}$} & $\mathrm{P}$ & 0 & 0 & 1 & 1 & 1 & 0 & 1 & 0 & 1 & 0 & 1 & 2 & 1 \\
\hline & $\mathrm{C}$ & 0 & 0 & 1 & 1 & 1 & 1 & 2 & 0 & 1 & 0 & 1 & 1 & 1 \\
\hline
\end{tabular}

For $P$. aeurginosa isolates there was no statistical association between the tested antibiotics. The association between the seasons and the antibiotics ceftazidime and imipenem was obtained by the genes blaSHV, blaCMY and blaNDM, with $p$-value $<0.05$. The gene associations analyzed occurred in blaVIM with blaSHV, blaCTXM, blaOXA and blaNDM ( $p$-value <0.05); blaKPC with blaCMY; blaSHV with blaCTX-M, blaCMY and blaNDM ( $p$-value <0.05); blaCTX-M with blaCMY and blaTEM ( $p$-value $<0.04)$; and blaCMY with blaNDM (p-value $<0.05)$.

The statistical association between antibiotics and genes ocurred on cefepime with blalMP; ceftazidime with blaVIM, blaSHV and blaIMP; imipenem with blaSHV, blaCMY and blaTEM ( $p$-value $<0.05)$. The results obtained from the phenotypic antibiogram for the aztreonam, gentamicin and Piperacillin / Tazobactam antimicrobials did not show statistically significant association with any of the genes studied in this study.

\section{Discussion}

The surgical opening in tracheostomized patients for the device installation causes a breakdown of the skin barrier and causes these microorganisms to become pathogenic ${ }^{1,5}$. 
In the present study, of the $27 \mathrm{~S}$. aureus isolated, were found resistance that are similar to the study developed by Cavalcanti et al. ${ }^{29}$, that found $83.6 \%(53 / 123)$ of resistance to penicillin, $26.2 \%(16 / 123)$ to cefoxitin, $16.4 \%(10 / 123)$ to erythromycin, $11.5 \%(7 / 123)$ to tetracycline, $9.8 \%(6 / 123)$ to clindamycin, and $100 \%$ of susceptibility to gentamicin.

To confirm the $S$. aureus specie identified, femA gene was used and was found in $100 \%$ of the samples. The phenotypic resistance to penicillin may be confirmed with the blaZ gene amplification, even on chromosomal DNA, that plasmidial DNA. The resistance acts in other types of penicillins as amoxicillin, ampicillin and piperacillin. However, stable penicillins such as oxacillin and methicillin, cephalosporins, $\beta$ lactamase inhibitors and carbapenems are not included ${ }^{30,31}$.

The methicillin resistance mediated by mecA gene can be phenotypically identified by cefoxitin, as identified in this study. This gene is responsible for the synthesis of a modified penicillin binding protein (PBP2a), which interferes with the formation of the bacterial cell wall, preventing its complete structuring ${ }^{32}$.

In SCCmec it's also possible to find resistance genes for macrolides, quinolones and lincosamines, which have antimicrobial resistance to CIP, ERI, CLI, GEN, among others, increasing the resistance to the group of macrolides, lincosamines and streptogramins, one of the most used in the treatment of staphylococcal infections. However, resistance to these antimicrobials has already been pointed out due to the constant vancomycin use and the easy acquisition of plasmids containing encoded genes to citoplasmatic membrane proteins that acts as efflux pump related to tetracycline ${ }^{12,33,34}$.

Inducible resistance to clindamycin was found in D test in $51.8 \%(14 / 27)$ of isolates, which limits its effectiveness as a treatment option in MRSA infections. Therefore, the application of $D$ test in the laboratorial routine is useful to investigated possible clindamycin resistance that helps the clinician in the effective use of clindamycin when this was a therapeutic option ${ }^{35}$.

For $P$. aeruginosa, in the present study, phenotypic resistance were identified to the antibiotics ATM, IPM, CAZ, PPT, CPM, CIP and GEN, similar to Pires et al. ${ }^{36}$ study, that identified resistance to $47.1 \%(46 / 87)$ CIP, 74.4\% (21/82) ATM, 45\% (74/170) CPM, 46.6\% (69/148) GEN and 18.2\% (14/77) IPM. The results suggested that $P$. aeruginosa resistance found is due the $\beta$-lactamases enzymes production and due the modification of the cell wall outer membrane permeability through the loss or reduction of porins, or by overexpression of efflux pumps present in the plasmatic membrane ${ }^{37}$.

In the $P$. aeruginosa samples, the most prevalent resistance genes encoding $\beta$-lactamase enzymes were blaOXA, blaKPC, blaVIM, blaCMY, blaTEM e blaSHV. The first two encode carbapenemases enzymes, blaVIM encodes metallo- $\beta$-lactamases, blaCMY ampicillins and the last two ES $\beta$ L enzymes ${ }^{37,38,39}$. The " $\mathrm{D}$ " and " $\mathrm{H}$ " samples stood out due to the great genetic variation and according to previous bibliographic research, we can observe the variety of antimicrobials that are inactivated when there is the expression of the mentioned enzymes (Table 5). 
Table 5 - Correlation of resistance genes for $\beta$-lactamases production found in two strains of Pseudomonas aeruginosa and the enzyme target antibiotics.

\begin{tabular}{|c|c|c|c|c|c|c|c|c|c|c|}
\hline ole & blaTEM & blaCMY & blaNDM & blaIMP & blaOXA & blaCTX-M & blaSHV & blaKPC & blaVIM & \\
\hline & $\begin{array}{c}\text { PEN, PPT, } \\
\text { CRO, CPM, } \\
\text { ATM, CAZ, } \\
\text { AMC, CFO, } \\
\text { CFL }\end{array}$ & $\begin{array}{c}\text { PEN, PPT, } \\
\text { CRO, ATM, } \\
\text { CAZ, AMC, } \\
\text { CFO, CFL }\end{array}$ & $\begin{array}{l}\text { ATM, } \\
\text { CAZ, } \\
\text { AMC, } \\
\text { CFO, } \\
\text { IPM }\end{array}$ & $\begin{array}{l}\text { CPM, } \\
\text { CAZ, } \\
\text { IPM }\end{array}$ & $\begin{array}{l}\text { CPM, } \\
\text { ATM, } \\
\text { CAZ, } \\
\text { IPM }\end{array}$ & $\begin{array}{c}\text { PEN, PPT, } \\
\text { CRO, CPM, } \\
\text { ATM, CAZ, } \\
\text { AMC, CFO, } \\
\text { CFL }\end{array}$ & $\begin{array}{c}\text { PEN, PPT, } \\
\text { CRO, ATM, } \\
\text { CAZ, AMC, } \\
\text { CFL }\end{array}$ & $\begin{array}{c}\text { PPT, CRO, } \\
\text { CPM, } \\
\text { ATM, CAZ, } \\
\text { CFL, IPM }\end{array}$ & $\begin{array}{l}\text { PPT, } \\
\text { CPM, } \\
\text { ATM, } \\
\text { CAZ, } \\
\text { IPM }\end{array}$ & \\
\hline ole & blaTEM & blaCMY & blaNDM & blaIMP & blaOXA & blaCTX-M & blaSHV & blaKPC & blaVIM & blaSPM \\
\hline & $\begin{array}{c}\text { PEN, PPT, } \\
\text { CRO, CPM, } \\
\text { ATM, CAZ, } \\
\text { AMC, CFO, } \\
\text { CFL }\end{array}$ & $\begin{array}{c}\text { PEN, PPT, } \\
\text { ATM, CAZ, } \\
\text { AMC, CFO, } \\
\text { CFL }\end{array}$ & $\begin{array}{l}\text { ATM, } \\
\text { CAZ, } \\
\text { AMC, } \\
\text { CFO, } \\
\text { IPM }\end{array}$ & $\begin{array}{l}\text { CPM, } \\
\text { CAZ, } \\
\text { IPM }\end{array}$ & $\begin{array}{c}\text { CPM, } \\
\text { ATM, } \\
\text { CAZ, } \\
\text { IPM }\end{array}$ & $\begin{array}{c}\text { PEN, PPT, } \\
\text { CPM, ATM, } \\
\text { CAZ, AMC, } \\
\text { CFO, CFL }\end{array}$ & $\begin{array}{c}\text { PEN, PPT, } \\
\text { ATM, CAZ, } \\
\text { AMC, CFL }\end{array}$ & $\begin{array}{c}\text { PPT, CRO, } \\
\text { CPM, } \\
\text { ATM, CAZ, } \\
\text { CFL, IPM }\end{array}$ & $\begin{array}{l}\text { PPT, } \\
\text { CPM, } \\
\text { ATM, } \\
\text { CAZ, } \\
\text { IPM }\end{array}$ & $\begin{array}{l}\text { CAZ, } \\
\text { IPM }\end{array}$ \\
\hline
\end{tabular}

Subtitle: PEN: Penicillin; PPT: Piperacillin + Tazobactam; CRO: Ceftriaxone; CPM: Cefepime; ATM: Aztreonam; CAZ: Ceftazidime; AMC: Amoxicillin + Clavulanic Acid; CFO: Cefoxitin; CFL: Cephalothin; IPM: Imipenem.

Analyzing the amplitude of each enzyme resistance, the samples can be considered multiresistant ${ }^{40}$, because the genes simultaneous expression is capable of inactivate the action of AMC and PPT antimicrobials belonging to the class of $\beta$-lactams, from first generation of cephalosporins to fourth generation ${ }^{32}$.

The antibiogram tests results didn't have phenotypical resistance to the tested antibiotics. This divergence occurs, because only the presence of the gene responsible for antimicrobial resistance isn't automatically linked to its expression ${ }^{41}$.

The antimicrobials $\beta$-lactams are the most used in bacterial respiratory tract infections, because they are highly effective and low toxicity ${ }^{42}$. Bellés et al. ${ }^{43}$ identified that of the 160 patients studied (adults and children), 80 did antibiotic therapy with $\beta$-lactams, which in 16 of these was identified metallo- $\beta$ lactamase enzyme activity. In addition, national epidemiological studies evaluated 3728 gram positive and gram negative isolates, and $P$. aeruginosa was responsible for $496(13.3 \%)$ cases, being the third pathogen most frequent that presented $30.2 \%$ of IPM resistance ${ }^{44}$.

Carbapenems are the most important antibiotics in the treatment of multiresistant $P$. aeruginosa infections. The resistance granted to this class makes treatment difficult ${ }^{11,45}$.

Regarding seasonality, there was no significant variation in the diversity of the microbiota throughout the year. This finding was similar to that described by Perez-Losada et al. ${ }^{46}$, Who also did not observe a 
difference in the tracheal secretion microbiota during the seasons.

It was expected to find changes in the microbiota mainly in winter, but the absence of this variation can be explained by the location of the tube, found in the trachea whose colonization differs when compared to the respiratory tract infections, where there is in fact a microbiological diversity that can be influenced by seasonality, due to greater contact with the external environment, as well as the presence of anatomical structures that contribute to microbiological control ${ }^{47,48}$.

The data from this study confirm that there is a relationship of infections occurring in lower respiratory tract of tracheostomized patients, with resistant bacteria. The cannula microbiota is influenced by the care of device hygiene and its permanence, when used for a long period, can lead to tracheal mucosa inflammation, increasing the risks of infections ${ }^{1,47,49}$.

Taechowisan et al. ${ }^{50}$ verified the relationship between the phenotypic and genotypic resistance and found that those based on PCR did not completely correlate with the phenotypic resistance, which was also found in this study of bacterial isolates from tracheostomized children. Mohaman and Menon ${ }^{51}$ also find coexistence of bla genes for metallo- $\beta$-lactamases in $P$. aeruginosa.

Researchers suggest the importance of changing the device regularly, since the patients in the present study performed this change once a month, and even so, a diversity of microorganisms was found, as well as biofilm-forming bacteria. Thus, if we consider patients who do not change the cannula frequently, they will probably present an intense and prolonged colonization, making the device a reservoir of bacteria, with the formation of persistent biofilm ${ }^{52}$.

In Brazil, tracheostomy tubes are not available free of charge by the Public Health System, making patients pay with the purchase of the device and often do not have the financial resources to do so, which makes monthly changes difficult ${ }^{52}$. In addition, the chances of biofilm adherence increase, resulting in the formation of granulation tissue, recurrent infections and failure in laryngotracheal reconstruction ${ }^{53}$.

Prolonged intubation and upper airway obstruction are frequent indications for tracheostomy, as well as acute respiratory failure and neurological disorders or injuries, which, according to some authors, are the least usual indications ${ }^{54,55,56}$. Regarding age, several studies show that tracheostomy is performed more frequently in pediatric patients, with higher rates being observed in children under one year old, newborns and premature, thus increasing the survival of this public ${ }^{56,57,58,59,60,61 .}$

Due to the increased survival, tracheostomy has become a constant practice for those children who need mechanical ventilation, but the initial management is with endotracheal intubation. However, this intubation for long periods brings several problems to the patient, such as mucosal ulcers and ischemia of the larynx or trachea, which justifies the commonly indicated tracheostomy ${ }^{58}$.

The knowledge of the predominant microbiota in lower respiratory tract infections as a result of device use in tracheostomized patients, as well as the resistance profile of the most antimicrobial used, will help 
health professionals regarding the most appropriate therapy to be given children with traqueostomy, especially in the postoperative period, increasing the chances of airway restoration and decannulation, since local hygiene is not always performed as recommended ${ }^{27}$.

\section{Conclusion}

The $S$. aureus phenotypic tests identified resistance to $\beta$-lactams groups, macrolides, lincosamines, aminoglicosides and tetracyclines. In $P$. aeruginosa, the phenotypic tests identified resistence to all antibiotics tested.

Resistance genes as blaZ e mecA in S. aureus and genes blaTEM, blaNDM, blaOXA, blaCMY, blalMP, blaCTX-M, blaSHV, blaKPC, blaVIM and blaSPM in P. aeruginosa. The amplified genes are correlated with the antibiogram data.

\section{Declarations}

Ethics approval and consent to participate

The research project was submitted and approved by the Ethics Committee of the Clinical Hospital of the Federal University of Goiás (CEP/HC/UFG), by number 32091014.6.1001.5078.

Consent for publication

Not applicable.

\section{Availability of data and materials}

All data generated or analysed during this study are included in this published article [and its supplementary information files].

\section{Competing interests}

The authors declare that they have no competing interests.

\section{Funding}

Not applicable.

\section{Authors' contributions}

All authors have made substantial contributions to the conception and design of the work, contributions with acquisition analysis, interpretation of data and have revised it. Besides, all authors have approved the submitted version (and any substantially modified version that involves the author's contribution to the study), and have agreed both to be personally accountable for the author's own contributions and to 
ensure that questions related to the accuracy or integrity of any part of the work, even ones in which the author was not personally involved, are appropriately investigated, resolved, and the resolution documented in the literature.

\section{Acknowledgements}

Not applicable.

\section{Footnotes}

Not applicable.

\section{References}

[1] SANDERS, C.D.; GUIMBELLOT, J.S.; MUHLEBACH, M.S. et al. Traqueostomy in children: epidemiology and clinical outcomes. Pediatric Pulmonology. 53 (2018) 1269-1275.

[2] FRIEDBERG, SA, GRIFFITH TE, HASS GM. Histologic changes in the trachea following Tracheotomy. Annals of Otology, Rhinology and Laryngology.74 (1965) 785-798 citado por EL CHEIKH, M.R.; BARBOSA, J.M.; CAIXÊTA, J.A.S. et al. Microbiology of traqueal secretions: what to expect with children and adolescentes with traqueostomies. International Archives of Otorhinolaryngology. 22 (2018) 50-54.

[3] RODNEY, J.; OJANO-DIRAIN, C.P. ANTONELLI, P.J. et al. Effect of repeated Tracheotomy tube reprocessing on biofilm formation. Laryngoscope. 126 (2016) 996-999.

[4] RUSSELL C.J.; MACK, W.J.; SCHRAGER, S.M. et al. Care variations, length of stay and readmission in children hospitalized for bacterial Tracheotomy-associated respiratory infections. Hospital Pediatric. 7 (2017) 16-23.

[5] CHEN, Y.E.; FISCHBACH, M.A.; BELKAID, Y. Skin microbiota-host interactions. Nature. 553 (2018) 427543.

[6] MATOS, E.C.O.; MODESTO, N.S.; COSTA, W.L.O. et al. Prevalência de agentes microbianos e sensibilidade da Pseudomonas aeruginosa. Revista Paraense de Medicin. 28 (2014) 35-43.

[7] POZZI, M.; PELLEGRINO P.; GALBIATI S. et al. Prevalence of respiratory colonisations and related antibiotic resistances among paediatric tracheostomised patients of a long-term rehabilitation centre in Italy. European Journal of Clinical Microbiology \& Infectious Diseases. 34 (2015) 169-175.

[8] COSTERTON, J.W.; STEWART, P.S.; GREENBERG, E.P. Bacterial Biofilms: A Common Cause of Persistent Infections. Science (1999).

[9] LIPOVÝ, B.; BRYCHTA, P.; ŘIHOVÁ, H. et al. Effect of timing of tracheostomy on changes in bacterial colonisation of the lower respiratory tract in burned children. Burns. 2013;39(2):255-61. 
[10] TENOVER, F.C. Development and spread of bacterial resistance to antimicrobial agentes: an overview. Bacterial Resistance to Antimicrobial Agents. 33 (2001) 108-115.

[11] LIMA, C.C.; BENJAMIM, S.C.C.; SANTOS, R.F.S. Mecanismo de resistência bacteriana frente aos fármacos: uma revisão. Cuidarte Enfermagem. 11 (2017) 105-113.

[12] TRABULSI LR, ALTERTHUM F. Microbiologia. $6^{\text {a }}$ ed. Rio de Janeiro: Atheneu; 2015.

[13] WORLD HEALTH ORGANIZATION. Antimicrobial Resistance. 2018.

[14] PROCOP GW. et al. Koneman Diagnóstico Microbiológico: Texto e atlas colorido. 7ed. Rio de Janeiro: Guanabara Koogan; 2018.

[15] BRASIL. Microbiologia clínica para o controle de infecção relacionada à assistência à saúde. Agência Nac Vigilância Sanitária - Anvisa. 2013.

[16] FREEMAN, D.J.; FALKINER, F.R.; KEANE, C.T. New method for detecting slime production by coagulase negative staphylococci. J Clin Pathol (1989).

[17] TENDOLKAR, P.M.; BAGHDAYAN, A.S.; GILMORE, M.S. et al. Enterococcal surface protein, Esp, enhances biofilm formation by Enterococcus faecalis. Infect Immun (2004).

[18] BAUER, A.W. et al. Antibiotic susceptibility testing by a standardized single disk method. Am. J. Clin. Microbiol. 40 (1966) 2413-5.

[19] Clinical and Laboratory Standards Institute. Performance standards for antimicrobial susceptibility testing. 2018.

[20] MARTINEAU, F.; PICARD, F.J.; LANSAC, N. et al. Correlation between the resistance genotype determined by multiplex PCR assays and the antibiotic susceptibility patterns of Staphylococcus aureus and Staphylococcus epidermidis. Antimicrobial Agents and Chemotherapy. 44 (2000) 231-238.

[21] LIN, Q.; XU, P.; LI, J. et al. Direct bacterial loop-mediated isothermal amplification detection on the pathogenic features of the nosocomial pathogen - methicillin resistant Staphylococcus aureus strains with respiratory origins. Microbial Pathogenesis. 109 (2017) 183-188.

[22] JACOBY, G.A.; MUNOZ-PRICE, L.S. The new $\beta$-lactamases. The New England Journal of medicine. 352 (2005) 380-391.

[23] LEE, K.; YONG, D.; YUM, J.H. et al. Evaluation of Etest MBL for detection of blaIMP-1 and blaVIM-2 allele-positive clinical isolates of Pseudomonas spp. and Acinetobacter spp. J. Clin. Microbiol. 43 (2005) 942-944.

[24] WALSH, T.R.; TOLEMAN, M.A.; POIREL, L. et al. Metallo-beta-lactamases: The quiet before the storm? Clin Microbiol Rev. 18 (2005) 306-325. 
[25] PICOLI, S.U. Metalo- $\beta$-lactamase Pseudomonas aeruginosa. Revista Brasileira de Análises Clínicas. 40 (2008) 273-277.

[26] DOGONCHI, A.A.; GHAEMI, E.A.; ARDEBILI, A. et al. Metallo- $\beta$-tactamase-mediated resistance among clinical carbapenem-resistant Pseudomonas aeruginosa isolates in northern Iran: A potential threat to clinical therapeutics. Tzu Chi Medical Journal. 30 (2018) 90-96.

[27] EL CHEIKH, M.R.; BARBOSA, J.M.; CAIXÊTA, J.A.S. et al. Microbiology of traqueal secretions: what to expect with children and adolescentes with traqueostomies. International Archives of Otorhinolaryngology. 22 (2018) 50-54.

[28] SHARMA, G.; RAO, S.; BANSAL, A. et al. Pseudomonas aeruginosa biofilm: Potential therapeutic targets. Biologicals (2014).

[29] CAVALCANTI, V.P.; CAMARGO, L.A.; MOURA, F.S. et al. Staphylococcus aureus in tonsils of patients with recurrent tonsillitis: prevalence, susceptibility profile, and genotypic characterization. The Brazilian Journal of Infectious Diseases. 2019.

[30] FERREIRA, A.M.; MARTINS, K.B.; SILVA, V.R. et al. Correlation of phenotypic tests with the presence of the blaZ gene for detection of beta-lactamase. Brazilian Journal of Microbiology. 48 (2017) 159-166.

[31] Clinical and Laboratory Standards Institute. Performance standards for antimicrobial susceptibility testing. 2019.

[32] KAUR, D.C.; CHATE, S.S. Study of antibiotic resistance pattern in methicillin resistant Staphylococcus aureus with special reference to newer antibiotic. Journal of Global Infectious Diseases. 7 (2015) 78-84.

[33] CARVALHO, M.J.; PIMENTA, F.C.; HAYASHIDA, M. et al. Prevalence of methicillin-resistant and methicillin-susceptible $S$. aureus in the saliva of health professionals. Clinics. 64 (2009) 295-302.

[34] SHIBABAW, A.; ABEBE, T.; MIHRET, A. Antimicrobial susceptibility pattern of nasal Staphylococcus aureus among Dessie Referrral Hospital health care workers, Dessie, Northeast Ethiopia. International Journal of Infectious Diseases. 25 (2014) 22-25.

[35] ROCHA, I.V.; FERRAZ, P.M.; FARIAS, T.G.S. et al. Resistência de bactérias isoladas em equipamentos em unidade de terapia intensive. Acta Paul Enferm. 28 (2015) 433-439.

[36] PIRES, E.J.V.C.; JÚNIOR, V.V.S.; LOPES, A.C.S. et al. Análise epidemiológica de isolados clínicos de Pseudomonas aeruginosa provenientes de hospital universitário. Revista Brasileira de Terapia Intensiva. 21 (2009) 384-390.

[37] AGHAZADEH, M.; HOJABRI, Z.; MAHDIAN, R. et al. Role of efflux pumps; MexAB-OprM and MexXY(OprA), AmpC cephalosporinase and OprD porin in non-metallo- $\beta$-lactamase producing Pseudomonas 
aeruginosa isolated from xystic fibrosis and burn patients. Infectious, Genetics and Evolution. 24 (2014) 187-192. https://doi.org/10.1016/j.meegid.2014.03.018.

[38] JUAN, C.; MOYÁ, B.; PÉREZ, J.L. et al. Stepwise upregulation of the Pseudomonas aeruginosa chromosomal cephalosporinase conferring high-level $\beta$-lactam resistance involves three AmpD homologues. Antimicrobial Agents and Chemotherapy. 50 (2006) 1780-1787.

[39] SANTIAGO, G.S.; MOTTA, C.C.; BRONZATO, G.F. et al. Revisão: produção de $\beta$-lactamases do tipo AmpC em Enterobacteriaceae. Revista Brasileira de Medicina Veterinária. 38 (2016) 17-30.

[40] MAGIORAKOS, A.P.; SRINIVASAN, A.; CAREY, R.B. et al. Multidrug-resistant, extensively drug-resistant and pandrug-resistant bactéria: an international expert proposal for interim standard definitions for acquired resistance. Clinical Microbiology Infection. 18 (2012) 268-281.

[41] KRALIK, P.; RICCHI, M. A basic guide to real time PCR in microbial diagnostics: Definitions, parameters, and everything. Frontiers in Microbiology. 8 (2017) 1-9.

[42] BUSH, K.; BRADFORD, P.A. $\beta$-lactams and $\beta$-lactamase inhibitors: an overview. Cold Spring Harbor Perspectives in Medicine. 2016.

[43] BELLÉS, A.; BUENO, J.; ROJO-BEZARES, B. et al. Characterisation of VIM-2-producing Pseudomonas aeruginosa isolates from lower tract respiratory infections in a Spanish hospital. European Journal of Clinical Microbiology \& Infectious Diseases. 37 (2018) 1847-1856.

[44] NEVES, P.R.; MAMLZUKA, E.M.; LEVY, C.E. et al. Pseudomonas aeruginosa multirresistente: um problema endêmico no Brasil. Jornal Brasileiro de Patologia e Medicina Laboratorial. 47 (2011) 409-420.

[45] POGUE, J.M.; BONOMO, R.A.; KAYE, K.S. Ceftazidime/Avibactam, Meropenem/Vaborbactam, or both? Clinical and formulary considerations. Reviews of Anti-Infective Agents. 68 (2019) 519-524.

[46] Pérez-Losada M, Graham RJ, Coquillette M, Jafarey A, Castro-Nallar E, Aira M, et al. The temporal dynamics of the tracheal microbiome in tracheostomised patients with and without lower respiratory infections. PLoS One. 2017;12(8):1-14.

[47] HASSOUN, A.; HUFF, M.D.; WEISMAN, D. et al. Seasonal variation of respiratory pathogen colonization in asymptomatic health care professionals: A single-center, cross-sectional, 2-season observational study. Am J Infect Control. 43 (2015) 865-870.

[48] Feng Z-H, Li Q, Liu S-R, Du X-N, Wang C, Nie X-H, et al. Comparison of Composition and Diversity of Bacterial Microbiome in Human Upper and Lower Respiratory Tract. Chin Med J (Engl). 2017 May 5 [cited 2019 Feb 10];130(9):1122-4.

[49] COLBEY, C.; COX, A.J.; PYNE, D.B. et al. Upper Respiratory Symptoms, Gut Health and Mucosal Immunity in Athletes. Sports Med. 48 (2018) 65-77. 
[50] TAECHOWISAN T, MUNGCHUKEATSAKUL N, PHUTDHAWONG WS. Antimicrobial Resistance Pattern of Staphylococcus aureus Strains Isolated from Clinical and Hospital Environment specimens and Their Correlation with PCR-based Approaches. Research Journal of Microbiology. 2018; 13:100-18.

[51] MOHANAM L, MENON T. Coexistence of metallo-beta-lactamase-encoding genes in Pseudomonas aeruginosa. The Indian journal of medical research. 2017 Jul;146(Suppl 1): S46.

[52] AVELINO, M.A.G. et al. First Clinical Consensus and National Recommendations on Tracheostomized Children of the Brazilian Academy of Pediatric Otorhinolaryngology (ABOPe) and Brazilian Society of Pediatrics (SBP). Brazilian Journal of Otorhinolaryngology. 83 (2017) 498-506.

[53] WANG JC, BERGERON M, ANDERSEN H et al. Feasibility of shotgun metagenomics to assess microbial ecology of pediatric tracheostomy tubes. The Laryngoscope. 2019 Feb;129(2):317-23.

[54] LAWRASON, A.; KAVANAGH, K. Pediatric tracheotomy: Are the indications changing? International Journal of Pediatric Otorhinolaryngology, v. 77, n. 6, p. 922-925, 2013.

[55] CHEUNG, N. H.; NAPOLITANO, L. M. Tracheostomy: Epidemiology, Indications, Timing, Technique, and Outcomes. Respiratory Care, v. 59, n. 6, p. 895-919, 2014.

[56] SCHWEIGER, C. et al. Traqueostomia em crianças: uma experiência de dez anos em um centro terciário do sul do Brasil. Brazilian Journal of Otorhinolaryngology, v. 83, n. 6, p. 627-632, 2017.

[57] TASCA, R. A.; CLARKE, R. W. Tracheocutaneous fistula following paediatric tracheostomy-A 14-year experience at Alder Hey Children's Hospital. International Journal of Pediatric Otorhinolaryngology, v. 74, n. 6, p. 711-712, 2010.

[58] FRAGA, J. C.; SOUZA, J. C. K. DE; KRUEL, J. Pediatric tracheostomy. Jornal de Pediatria, 12 mar. 2009.

[59] FUNAMURA, J. L.; DURBIN-JOHNSON, B.; TOLLEFSON, T. T.; HARRISON, J.; SENDERS, C. W. Pediatric tracheotomy: indications and decannulation outcomes. Laryngoscope, v. 124, n. 8, p. 1952-1958, 2015.

[60] NASSIF, C. et al. Tracheotomy in children: A series of 57 consecutive cases. European Annals of Otorhinolaryngology, Head and Neck Diseases, v. 132, n. 6, p. 321-325, 2015.

[61] DOHERTY C, NEAL R, ENGLISH C, et al. Multidisciplinary guidelines for the management of paediatric tracheostomy emergencies. Anaesthesia. 2018.

\section{Figures}




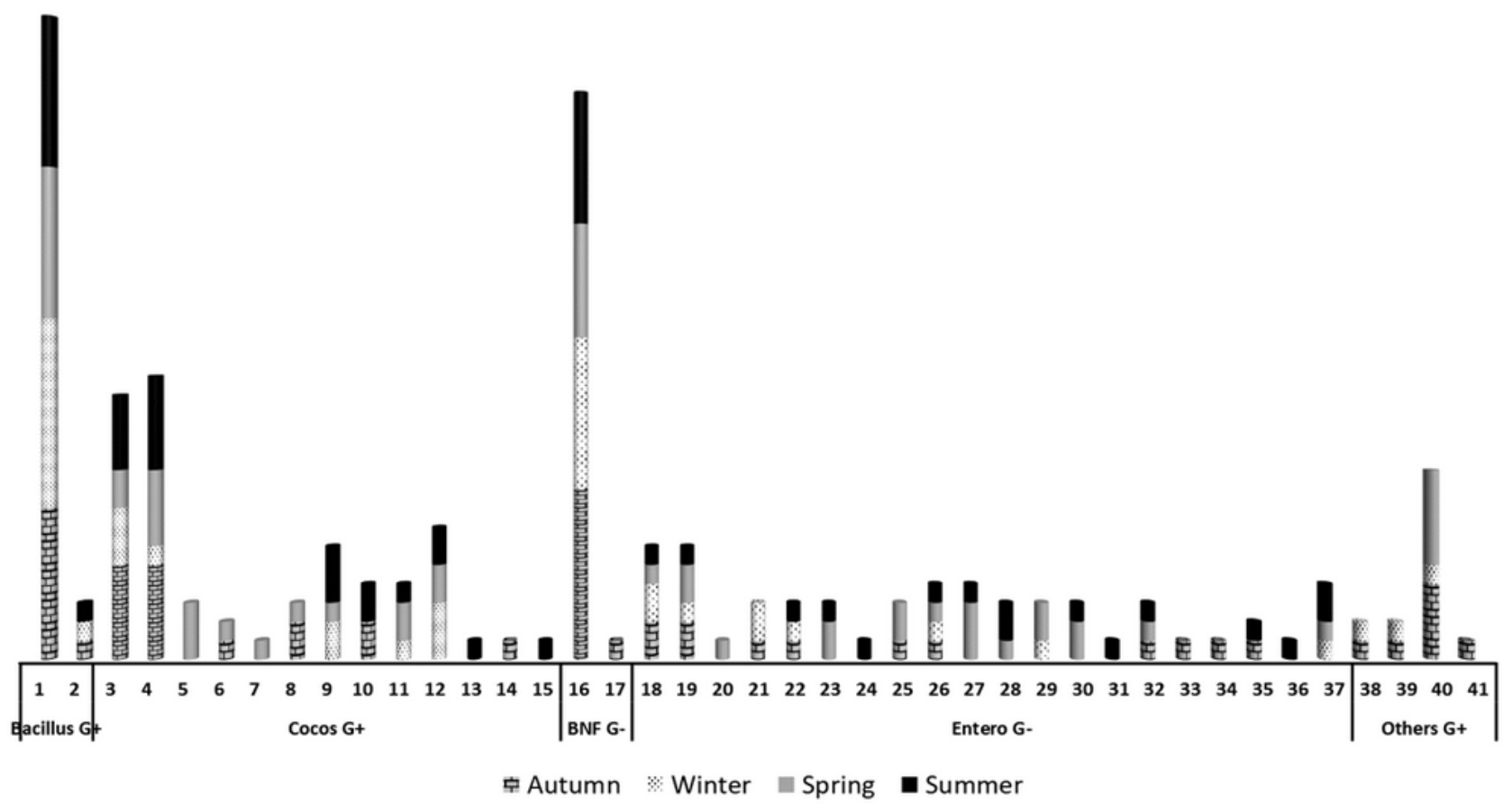

\begin{tabular}{|c|c|c|c|c|c|}
\hline 1 & Corynebacterium spp. & 15 & Stomatococcus spp. & 29 & Providencia spp. \\
\hline 2 & Bacillus spp. & 16 & Pseudomonas aeruginosa & 30 & Serratia entomophila \\
\hline 3 & Staphylococcus aureus & 17 & Acinetobacter Iwoffii & 31 & Serratia grimesii \\
\hline 4 & Staphylococcus coagulase negativa & 18 & Citrobacter spp. & 32 & Serratia liquefaciens \\
\hline 5 & Microbacterium spp. & 19 & Enterobacter aerogenes & 33 & Serratia marcescens \\
\hline 6 & Micrococus spp. & 20 & Enterobacter agglomerans & 34 & Serratia odorifera \\
\hline 7 & Planococcus spp. & 21 & Enterobacter cloacae & 35 & Serratia rubidae \\
\hline 8 & Staphylococcus epidermidis & 22 & Escherichia coli & 36 & Tatumella citrea \\
\hline 9 & Staphylococcus haemolyticus & 23 & Hafnia alvei & 37 & Yersinia aleksiciae \\
\hline 10 & Staphylococcus hominis & 24 & Klebsiella ascorbata & 38 & Sphingomonas spp. \\
\hline 11 & Staphylococcus hyicus & 25 & Klebsiella oxytoca & 39 & Stenotrophomonas maltophilia \\
\hline 12 & Staphylococcus intermedius & 26 & Klebsiella pneumoniae & 40 & Moraxella spp. \\
\hline 13 & Staphylococcus lugdunensis & 27 & Morganella morganii & 41 & Plesiomonas spp. \\
\hline 14 & Staphylococcus schileiferi & 28 & Proteus vulgaris & & \\
\hline
\end{tabular}

\section{Figure 1}

Diversity of bacterial species isolated from tracheal secretions of tracheostomized children according to seasons. Subtitle: G+ Gram positives; BNF G- No fermentative gram negative Bacillus; Others G- Others gram negative bacteria. 


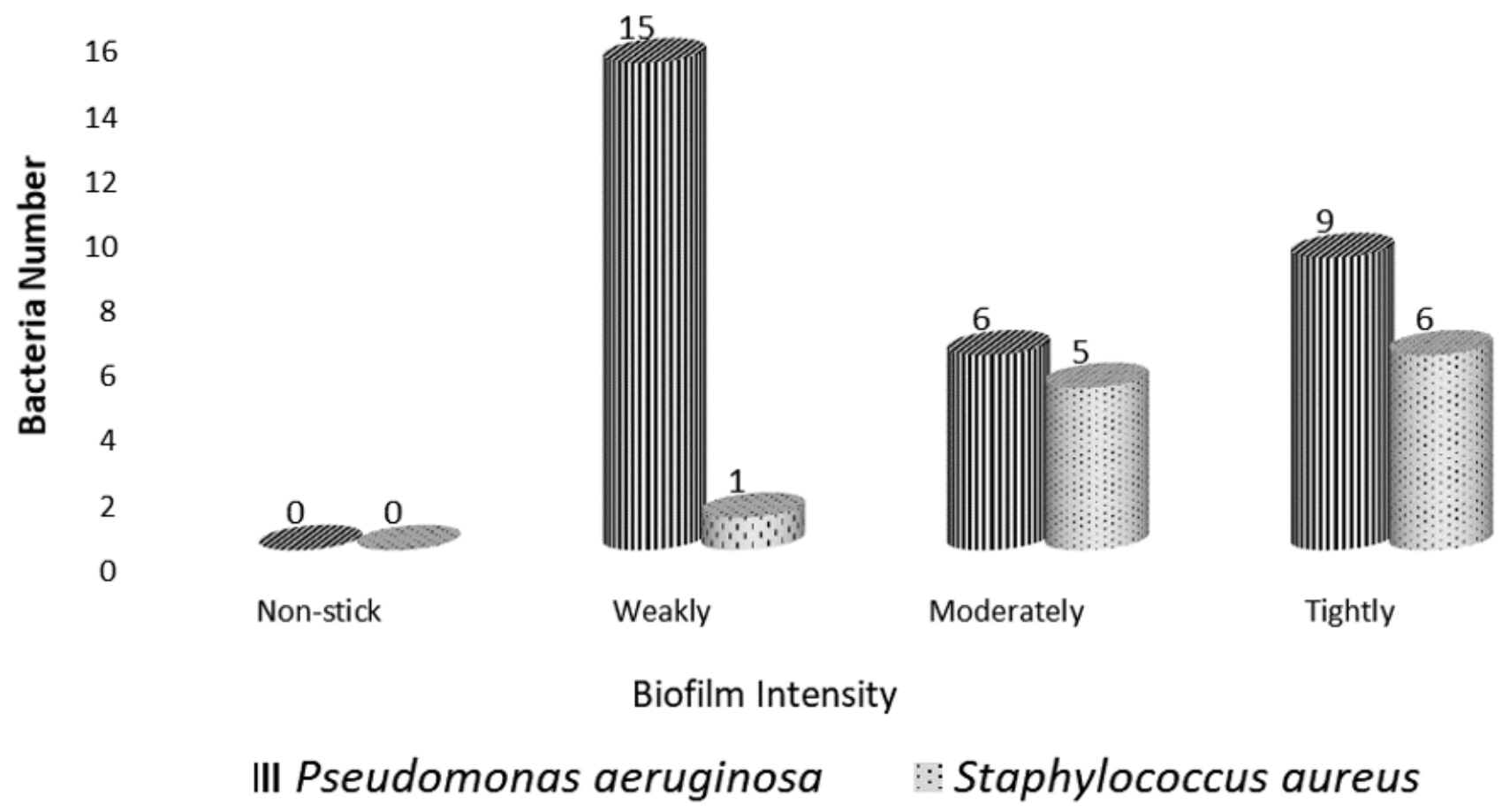

Figure 2

Adhesion intensity of the biofilm of Pseudomonas aeruginosa and Stahylococcus aureus from the tracheal secretions of traqueostomized children.

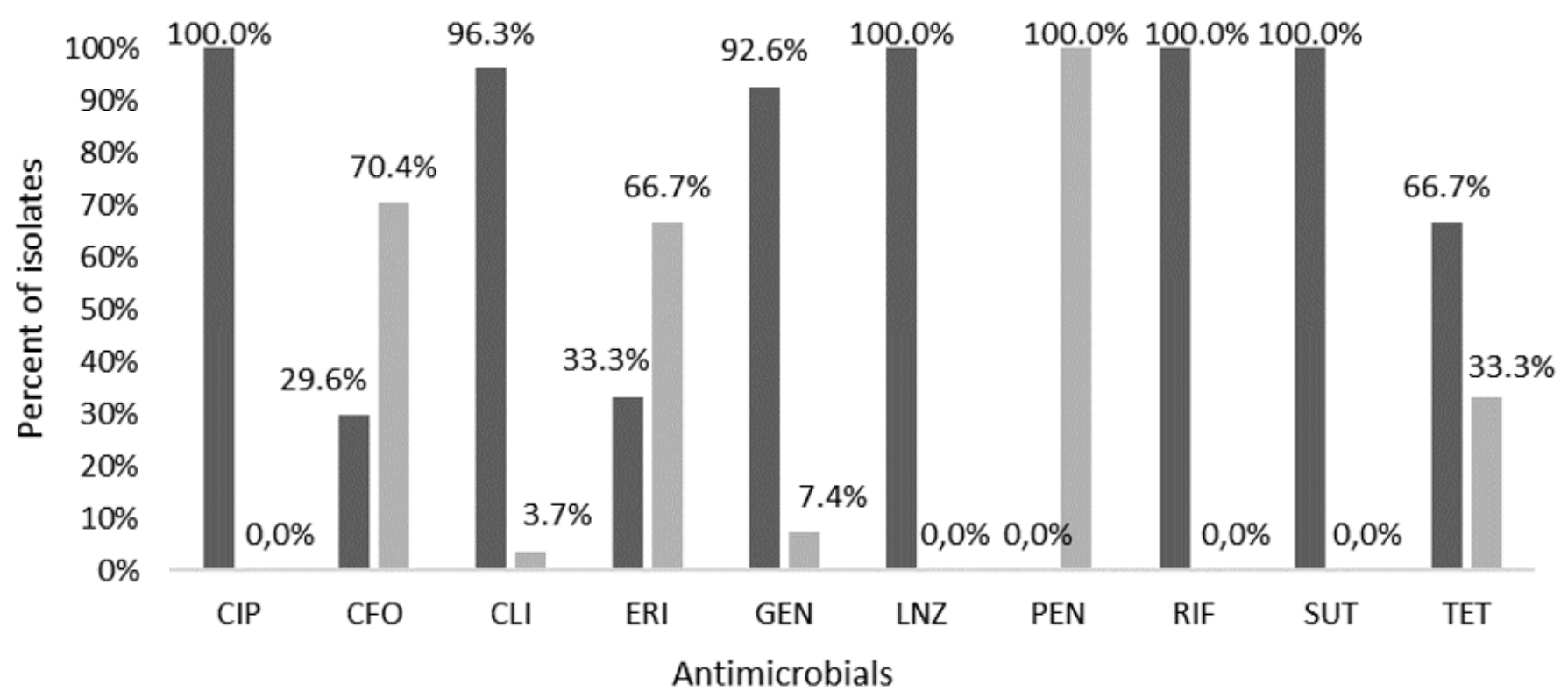

Sensitivity $\quad$ Resistance

Figure 3 
Phenotypic resistance profile of Staphylococcus aureus isolated from tracheostomized pediatric patients' tracheal secretion. Subtitle: CIP: Ciprofloxacin; CFO: Cefoxitin; CLI: Clindamycin; ERI: Erythromycin; GEN: Gentamicin; LNZ: Linezolide; PEN: Penicillin; RIF: Rifampicin; SUT: Sulfamethoxazole + Trimetoprim; TET: Tetracycline.

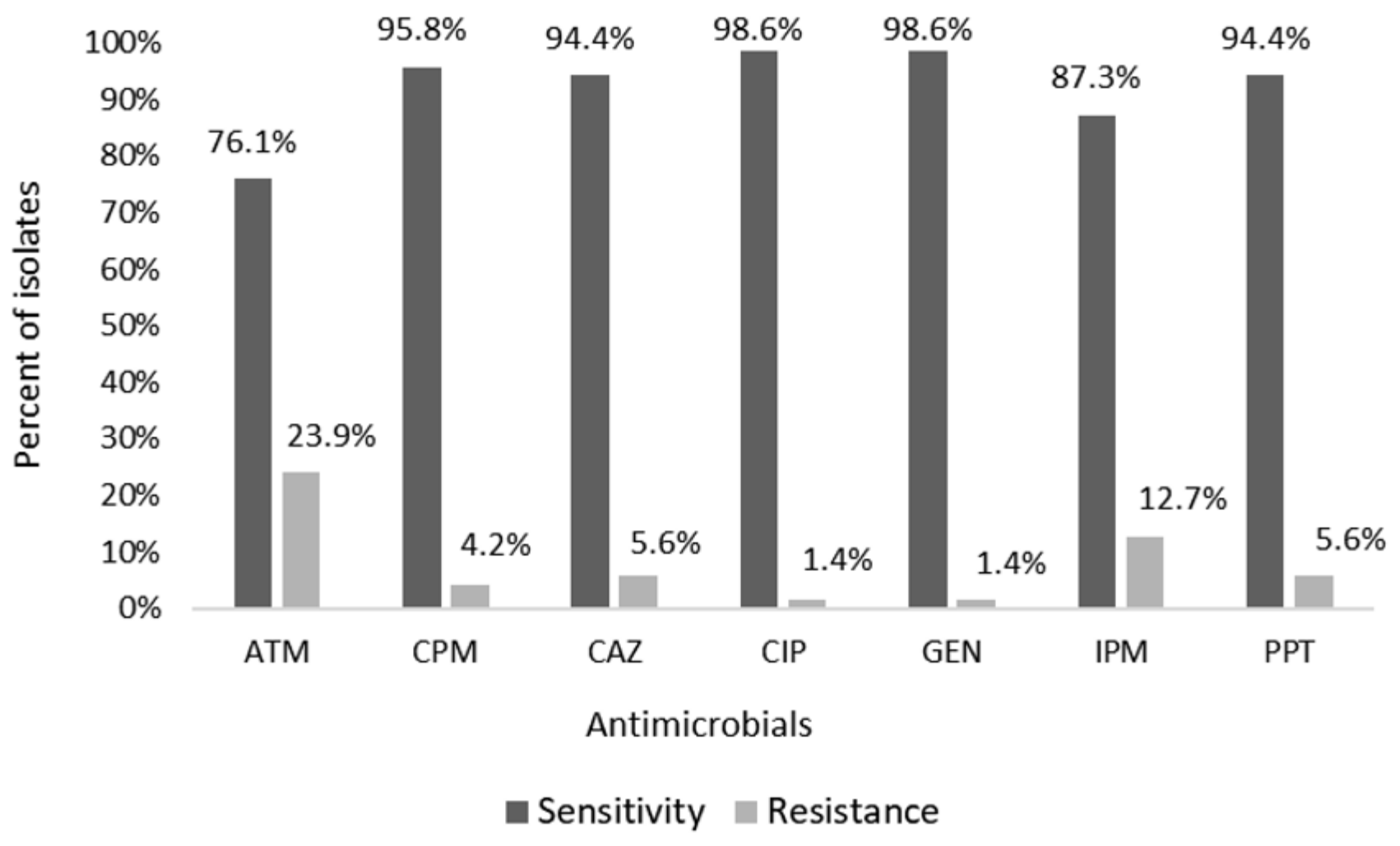

Figure 4

Phenotypic resistance profile of Pseudomonas aeruginosa isolated from tracheostomized pediatric patients' tracheal secretion. Subtitle: ATM: Aztreonam; CPM: Cefepime; CAZ: Ceftazidime; CIP: Ciprofloxacin; GEN: Gentamicin; IPM: Imipenem; PPT: Piperacillin + Tazobactam. 


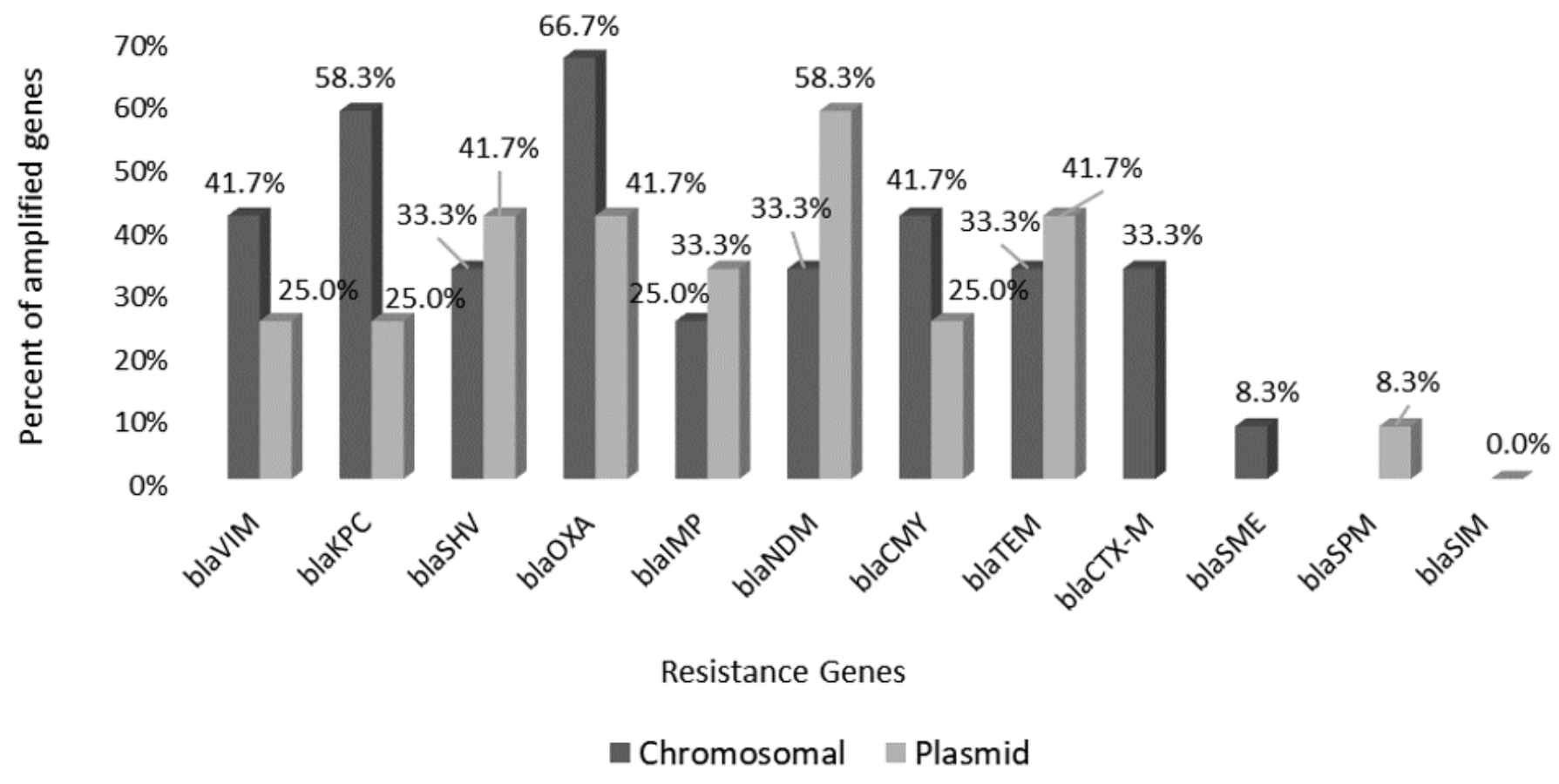

Figure 5

Resistance genes amplification in Pseudomonas aeruginosa samples isolated from tracheostomized pediatric patients. 